\title{
風土・文化の伝承の場としての里山
}

\section{Satoyama: The Field of Nature and Cuture's Taste}

北尾 邦伸*

Kuninobu KITAO

\section{1. 里山的自然とわれわれ}

土を踏む 風に聞く 声と出会うそして

はるかな時を見る $\cdots$

これはテレビで連続放映されている『街道をゆく』の, 出だしのナレーションである。司馬遼太郎が現地を訪れて しっかりと土を踏み，風を全身に満たして語り出すと，な んでもなかった風景が突然，生き生きと躍動をはじめる。

里山では, その土を耕し，農的営みを続けている人びと が生活をしている。

人間社会をとりまく環境的自然に「主体性」を働かせ, 同時に相手から「環境性」としての作用を受ける。これら やりとりのなかで結合され，全体として用をなす様式を， 川喜田二郎は「文化」とよんでいる1”。

大地を含めた風土としての文化。文化はもともと風土そ のあのだといってよいのかも知れない。そして里山は，日 本における「風土之しての文化の場」そうのあのである。

ところで，「時を見る」とはなにか。岩田慶治によると， 伝統社会の人びとは「時」を手で触れることのできるくも の〉として，観念していたという。 tangibleな姿としての 「時」は，当然眼で見ることができる。「時間」は「時のま」 としての「余的」であった ${ }^{3)}$ 。

近代科学を越えようとする岩田は, 文化の扔かれた場を とらえるには, 身体をとうして対象に接近し, 観察者は 「参与者」とならねばならないと述べている。参与すると は，死を含む場に歩み入るということである。このことな しに文化的支柱をその上に建立しているく隠れた自然〉を 「見る」ことはできないという。彼によると「文化」が， 形式をむった生きあのであるのに対し，「場」は形をあた 生きものである ${ }^{3)} 。$

現実の里山社会が，このような伝統社会のなかにあると は，いい難い。しかし，このような「はるかな時」を伝承 している，とみなすことあ不可能ではない。

この点はさておき，あう少し見える次元で，いま，里山 でなにが問題になっているのかを示しておこう。
「風景」が，主観的なあのと切り結ふ映像であるとすれ ば,「景観」はより客観的で, かつ, 㕕がり之構造をもっ た視覚的なものと考えることができる。この「景観」の手 法を村落史研究にとり入れたのは, 福田アジオであるが, 彼は, ムラ (集落), ノラ (耕地), ヤマ (林野) の領域形 成論として村落史をおさえよう之試みている4)。現在, こ の景観に現れたムラ・ノラ・ヤマの一体性は切り裂かれ， 見る人をして，風景が衰退したと感じさせている。

「生きられる景観」という概念は樋口忠彦のものだが， これは場所あるいは土地にかくされた固有の特性を発見し， それを創造的に人間生活に組み入れることにより成立させ てきた「好ましい棲息地」，の景観である5う。いま，里山 社会は, この環境形成力を著しく減退させている。

ところで私も所属している里山研究会では, 里山林とし ての里山だけでなく，それに隣接する水田や畦道や畑や茅 場, そしてため池や用水路を含めた景観を里山とよんでい る。この里山的自然の一体性は, 景観生態学によって明か にされつつあるが ${ }^{6)}$, かっての農的営みが崩れ, 多様な生 きあのにとってのすみかが分断され, 䘫失が進んでいる。 多くの昆虫や植物が生存の危機におちいっている。

私は，昔の里山的世界に回帰しょうとしているのではな い。衰退しつつも貫きとうしているものを発見し，今日的 な意味を付与して回復・修景を図りたく思っているのであ る。それにしても，それを誰が担うというのか。われわれ はどのようにして参加ないし参与をしえるというのか。

\section{2. 里山的世界}

かっての里山的世界には,「農的営み」としかいいょう のない（市場に対応しての発展をめざす「農業」のイメー ジと区別される）生業を担う農民がいて, 水や山の管理主 体としてのムラがあった。彼ら農民は, 米つくりや食料生 産にではなく，田をつくるノラ仕事に，もっといえば， 「田をこしらえる」ことに従事していたのである2)。 ヤマからは, 彼らの生業の一環として, 肥料用の草や山 
菜，そして，薪炭材や農用資材が採取されていた。薪炭林 は, クヌギやコナラなどの萌芽更新しやすい樹木で構成さ れていて, 伐ったあとは天然の回復力, 自然の循環の時間 を「待つ」というやり方で営まれていた。

太陽は西に沈んで一度死に，また東から再生してくるも のであり，地上の諸々の生命力は冬に向かって衰え，また 春にその力を吹き返してくるものであった。自然のリズム があり, 循環があり, そして, 田んぼに対しては, この世 界を確かなものにする「労働」の「蓄積」があった。すべ ての生きものが, 大地とのつながりで生きていた。自然と の一体感のなかで収穫を喜び, 軒先に薪を積み終えては, これで冬を越せると家族して安堵したことであろう。

ムラ・ノラ・ヤマ, そして互いが互いに見える範囲が村 落である。村落の外部にオクヤマと八ラがあり，そこは 「無縁」のものが棲む場所であった。しかし，その無縁の あのと村落の間にも興味深い相互関係の歴史があり ${ }^{4)}$, 里 は同心円状の広がりをあって開かれていた。オクヤマを介 してあの世ともつながり，いつもカミに見られていると感 じつつ自制し，また，感謝の念む抱いていた。

ムラには祭りが久かせないが，祭りの起こりには，折り 合いをつけて自然との間での約束ごとを改めていくという 契機が含まれていたとの見方 ${ }^{2)}$ は，おもしろい。万物は森 の客であり, 人間が一番遅れてやってきた客である。客は, 客らしい振舞いをしなければならない22。

共同体の息苦しさや，労働の過酷さは相当なむのであっ たであろう。しかし，いかなる生存状態にあろうと，人は 満足や楽しみを屯熱望している。環境的自然への情緒的な 結びつき。人間がもつ場所への愛情と愛着。イーフー・トゥ アンは,これを「トポフィリア (場所への愛)」としてテー

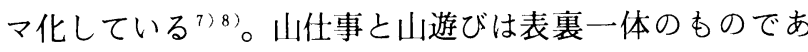
り, 稼ぎに追われる生活に変容した現段階においても, 人 びとは紅葉を愛でながら弁当を食べ, 川に遊び, 蜜蜂を手 なづけながら生活を楽しもうとしている ${ }^{9)}$ 。人間の精神が のびのびと自然のなかを遊び, 環境的自然への帰属＝同 化 ${ }^{2)}$ の意識が貫いていることが発見できよう。

すでに触れたが, 農的営みの小規模で多彩な生産のあり ようは, モザイク状の多様な環境的自然を形成し，この自 然を利用して野生生物が生息していた。これら総体が，かっ ての日本の身近な自然そのものであり,「うさき追いしか の山」であった。里山は里山としての豊かさのなかにあっ たのである。いま, 農業的展開のあとで里山的世界はその 一体性を分断され, 激しく分解している。とりわけ農地に 迫る里山林は放置され, うっそうとした常緑広葉樹林と化 して人を寄せつけず，農と林が切れた関係にあることをう かがわせている。近代化というフィルターをかけた眼で見 ることによって,「遅れた地域」となってしまった里山で, 人々も自然も苦悩しているといわざるをえない。

\section{3. 森と里の思想}

進化の限りをつくしている科学文明が状況を切り開き, 現在, アングロ・アメリカン型のグローバル・スタンダー ドの時代を迎えている。明治以来のキャッチアップ体制 (「地方のたかり中央の支配」）が崩壊にむかい，究極のと ころ「儲けで勝負し金で処理してどこが悪い」というオー プンな社会が到来している。このグローバリゼーションの 軸に対して, 生活者起点ないしは地域・文化の視点からの 価值軸をどのように設定していくかが問われている。

昔ながらのよさをいかに保持し伝承していくかは, ます ます困難で重要な課題となっていくであろう。自由な発想 からの市民参加や，種々の立場からの多様な取り組みが期 待されるが，そのためにも，できることなら将来社会に対 するパースペクティブを共有したいあのである。

地球温暖化防止京都会議で配られていた 2005 年愛知万 博の PR 誌の 2 枚の写真は, いずれもが里山らしき森を写 したものであった。また，掲げられていたテーマは，「Beyond Development: Rediscovering Nature's Wisdom」 となっていた。前者は，「現代文明からの解放」と考えら れる。後者は,「自然の䟾知の再発見」であるが，意味す るところは, 大地の恵みへの信頼の念の回復, ではなかろ うか。これらのより具体的なイメージが「森と里」という ことになる。自分の方に引き込み過ぎの解釈であろうか。

与えられた標題に沿って，ここまで苦し紛れな事を書い てきたが，高木仁三郎『いま自然をどうみるか』に触発 されなければ，全く筆が進まなかったであろう。

高木はこの著書を，「二つの自然」からはじめている。 私たちの自然観は, 科学的・理性的なものと感性的・身体 的なものとに激しく引き裂かれ, 人間の内なる「第一の自 然」は，征服されるべき自然の側に入れられてしまってい る。現在社会は合理性が強制力をあつ社会であり, そのも とで労㗢があり, 技術がある。それでいてこの合理性（科 学的・数学的秩序) は, 宇宙を解明できているわけではな い。これら現状と科学史を, 彼は説得的に述べている。

高木は生物の共生を積極的なものとしてとらえる視点を 獲得し,「生物界のつくる文化」という仮説を提出してい る。それは, 循環によって定常状態を維持しようとする開 放定常系としての生命系に関する基本的な考察に基づいて いる。全体として互いの生存条件を安定させるべく「成熟」 をとげようとすることを，彼は＜文化〉とよぶ。そして生 物全体の創出するく文化>の世界に, 人間の文化や営みを どのように合流させていくかを最大の課題としている。ま た, 人間の生や生活を自然の営みのなかに相対化すること にこそ，「人間の主体性」があると主張している。

彼のこのような主張は, 大地とのかかわりのなかで文化 をうちたてようとする「森と里の思想」にと連続している。 そして, その格好の舞台が里山となる。なお彼は, 科学か 
らは最大限に学ぶという柔軟な姿勢を保持している。

自然とのかかわり方で気になる岩田の説を再び紹介して おこう。彼は,「新たなアニミズム世界の創造」を提案し ている ${ }^{3)}$ 。彼によると，アニミズム世界は対応の論理によっ て貫かれている。そこでは，人と〈もの>，〈あの>と 〈むの>とが直接無媒介に対応する。直接無媒介に対応し 対座できるその場所は，〈隠れた自然>がその姿をあらわ すところである。そこでは，〈あの>とくあの>とが互い にその姿を交換する。鳥が風になり，花が石になる。その 場所は, 万物の変身するところである。彼は, 人間の営み の, 大地と一番近いところに，技術ではなくアニミズム的 宗教をおこうとしているのである。現代文明社会は，技術 が自然と人間の間にわけ入って決定的な力をむっている。 当然にも彼は，この点を意識している。

わかりやすい話に戻すと, 司馬遼太郎は「文明」を，た れあが参加できる普遍的なあの・合理的なるの・機能的な あのと規定し, 一方「文化」はむしろ不合理なもので, 特 定の集団においてのみ通用する特殊なすのとおさえている。 そして，現代にあって文明を生みつづける地域はアメリカ 以外にないと考えて，アメリカへの旅に出ている。スプリ ンクラーの装備で緑が維持されている現地に立って，この 国では大地に人間が載っているのではなく, エネルギーの 上に載っているのだと実感するくだりが紀行文にある11。

\section{4. 里山を生かす}

森と里の思想は，場における実践をとうしてしか明確に ならない。また，実践にこそ意味がある。

里山をどう生かすか。生かすとは, 相互主体的な関係の あとでは, 生かされるということと同じである。はたして われわれは, どのようにして里山的世界に入っていく，な いしは，つなげていくことができるのであろうか。

里山研究会が実践的課題として取り組んでいることは, 里山景観をワンセットとしてとらえ，それをセットとして 保全する運動である。市民農園を建設するのなら，ある幅 で帯状に林縁部に設置していく, といった提案も行ってい る。有機農業の展開を支援していくことも当然含まれる。

他方, 里山林を伐って, 炭や電気としてのエネルギー源 にすることにも力を注ぎ, 全国 2 千力所に小型の木ガスに よる熱電併給センターを建設する構想ももっている。木ガ ス発電は大気中に炭酸ガスを排出しない発電システムとし て，スウェーデンやデンマークでは国民的合意がえられ， 現に炭素税が課税されていない。発電の際には確かに炭酸 ガスを排出するが，それをまた森林が受け止めて吸収する から一定量が循環するだけ，と考えうるからである。

その間のロスを伴いながらあ電気は遠距離に送ることが できる。しかし，熱はそうはいかない。熱によって暖房も 冷房も可能であり, しかも冷暖房に大量の電力が使われて
いるというのに，遠隔地に立地した巨大技術装置としての 現行の発電システムは, エネルギーの6 割近くを熱として 無䭾に捨てている。これに対して，木ガスによるコージェ ネは, 分散型地域社会の建設にふさわしいエネルギー供給 システムであり，木を伐ることによって，明確に里山林の 保全にもつなげていくことができるのである。

ところで，造園家は森と里の思想の実践において，どの ような役割を担えるであろうか。里山景観を保全したり修 景したりする際に，おもむきを与えたり，味わい豊なもの にすることは，実に重要なことである。この議論は，「自 然美とはなにか」につながっていく。この点は,「緑」や 「風致」を意味深く考察している中村一に詨万う ${ }^{12)}$ 。

コトとしての時を重ね, 時間という「余白」の中に熟成 してくるく文化〉に造園家が合流していこうとすると，ど うしてもビジネスとしての立場からの参加と自家撞着する 局面が発生するであ万う。この問題は, 自分の問題として 個々に引き受けてあらうしかない。

いろいろ述べてきたが，はるかな時を見ることに，皆さ んに「主体的」に参加・参与されることを訴えたい。いや, そのような潮流はすでに多様に広範に形成され，互いに影 響を与えつつある。これはひょっとすれば，これからの社 会に向かう新しい文明といってよいのかす知れない。

最後に，中村一氏からの今年の年賀状を紹介しておこう。 そこには,「公教育の発生が寺子屋なら, 今こそ里山で遊 ぶ場『里子屋』の必要性が叫ばれるべきです」とあった。

\section{参考および引用文献}

1）川喜田二郎（1989）：環境之文化：河村武・高原榮重 編「環境科学 II 」, 朝倉書店

2 ）前田俊彦・高木仁三郎（1986）：森と里の思想：七つ 森書館

3 ）岩田慶治（1993）：コスモスの思想 : 岩波書店

4 ）福田アジオ（1982）：日本村落の民俗的構造 : 弘文堂

5 ）樋口忠彦 (1981) : 日本の景観 : 春秋社

6 ）田端英夫編著（1997）: 里山の自然 : 保育社

7) イーフー・トゥアン (1992)：トポフィリア：せりか 書房

8 ）北尾邦伸（1996）：暮しを守る緑の屏風：营原聰編 「森林 日本文化としての」：地人書館（ここで筆者は, 森をつれてハラに進出した出雲の築地松をめぐる農的 営みに,トポフィリアを意識して接近した。）

9 ）北尾邦伸（1992）：森林環境と流域社会：雄山閣出版

10）高木仁三郎（1985）：いま自然をどうみるか : 白水社

11）司馬遼太郎 (1986)：アメリカ素描 : 読売新聞社

12) 中村一 (1993)：自然美の擁護 : 退官記念シンポ冊子 